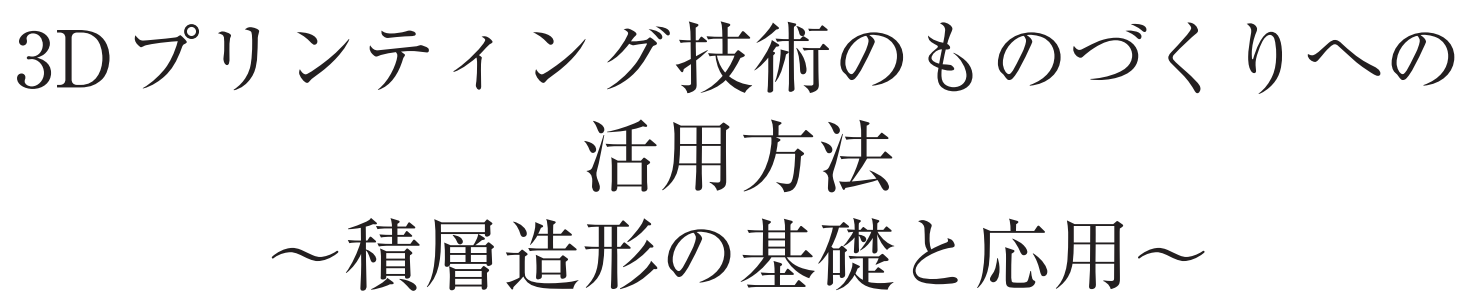

安 齋 正 博

\title{
Base and Application of the Additive Manufacturing in 3Dimentional Printer
}

Masahiro ANZAI (Department of Engineering Design, Shibaura Institute of Technology, 3-9-14 Shibaura, Minato-ku, Tokyo 108-8548, Japan)

Recently, the degree of attention of 3D printer increases and its use has been spreading. 3D printers taken up here are as follows; stereo lithography, selective laser sintering, ink jet printing, fused deposition molding, and laminated object manufacturing. Can 3D printer change Japan's manufacturing industry? It is described about the foundation and application whether it is fit for what kind of use. The examples of the application is raised in the following; produce (rapid manufacturing, on-demand parts, inspection), create (model, capture, sculpt), measure (precision metrology, inspection reporting, 3D documentation), prototyping (design verification, functional validation), and others.

Key Words : 3D Printer, 3D CAD Data, Additive Manufacturing

1. なぜ今3Dプリンターなのか

2012年ごろから積層造形 (Additive Manufacturing) に関して劇的な変化が訪れた。それは，3D プリンターと いう言葉が市民権を得つつあって，これを使用すればもの づくりに革新が起こるというキャッチフレーズが多くの雑 誌で取り上げられ，テレビやラジオでもよく見聞きするよ うになった。

最近では，3D プリンターを用いて殺傷能力を有する銃 を某大学職員が製作して物議を醸したりしている.しかし， この数年で造形機が画期的に変わったわけではない．以下 になぜこのようになったのかを分析して，これからどのよ うに3D プリンターを活用したら良いかについて基礎と展 望を述べ， 2,3 の事例について工学的見地から説明しょ う.

まず，オバマアメリカ合衆国大統領が，2012年の始め に, 今後 4 年間で 1,000 カ所の学校に $3 \mathrm{D}$ プリンターゃレー ザーカッターなどのデジタル工作機械を完備した「工作室」 を開くプログラムを起ち上げた。また，2012年 8 月には， $3 \mathrm{D}$ プリント技術を研究・発展させるためにオ八イオ州に 3000万ドルを投入して National Additive Manufacturing Innovation Instituteの設立を発表した。このあたりから
3D プリンターという言葉がよく使われるようになってき ており，それ以前には，3D プリンティングという言葉は あったが，3D プリンターという専門用語はなかった．3D プリンティングはインクジェットを使用して，スターチや 石膏パウダーを固める方法で, 文字通りプリンターに使用 するインクジェットを使用しており，これだとまさにプリ ンターそのものである.しかし, 現在 3D プリンターは Additive Manufacturing全体を指す言葉になってしまっ たようだ。

それとアメリカでのもう一つの出来事は, Chris Anderson という科学雑誌編集者が “Makers” というべストセ ラーを発刊したことも $3 \mathrm{D}$ プリンターを幅広く認知させた 要因の一つであろう. “The new industrial revolution” （日本語訳では「21世紀の産業革命が始まる」）というシ ヨッキングな題目の本であった ${ }^{1)}$ 。簡単に言えば，3D プ

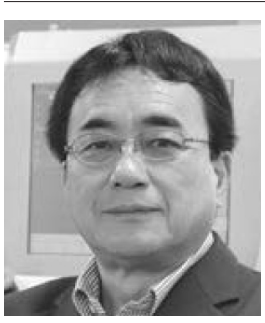

安齊 正博; 芝浦工業大学デザイン工学部デザイン工学科、理 工学研究科機械工学専攻 ( $108-8548$ 東京都港区芝浦 3-9-14) 教授, 工博. 昭和 63 年, 東京大学大学院工学系研究科博士課程 金属工学専門課程修了. 材料工学 (複合材料工学), 形状創製工 学(研磨・バリ取り, 溶接・溶射, 高速ミーリング,上ーザ加 学研究所客責, 主管研究, 員, 東京大学生産技術研究所研究員, 埋金 型技術振興財団理事, 「中小企業優秀新技術・新製品賞」尃門審 查委員, 素形材産業技術賞審查委貝, 型技術協会型寿命評価研

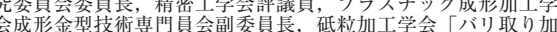
工石研磨布紙加工技術尃閏委員会」委員, IJ AT Editor, BEST-JAPAN研究会理事 等 
リンターを使えば，だれでもメーカーになれて，第二の産 業革命がここから始まるというような内容である.現在は， 我が国でも 20 種以上の $3 \mathrm{D}$ プリンターに関する本が上梓さ れている。

\section{3Dプリンターを動かすためのシステムと要素技術}

3D プリンターはあくまでも出力機であるから，ものつ くりを行う上では単なる道具の一つにすぎない. 現状のも のづくりのプロセスを図 1 に示す ${ }^{2)}$. 現在のものづくりは コンピュータを抜きには考えられない. 工業製品は一般的 には大量生産である。その際には金型を製作してプレス成 形や射出成形などで部品が製作される。設計には CAD (Computer Aided Design) が使用され，これの良否が CAE (Computer Aided Engineering) によってバーチャ ルで確認され，良ければCAM（Computer Aided Machining）でカッタパスを自動作成して，実際に数值制 御加工して金型部品を製作して，金型を組立・調整して， 射出成形機にセットして成形加工する工程がプラスチック 製品では一般的である。ここでの 3D プリンターの役割は， 試作品を CAD データから出力することが主目的であった が,最近では直接製品を製作できるようになってきており， まさにこれが注目されている。

さて，3D プリンターが活用されるためには種々の要素 技術がある程度のレベル以上に整っていなければならな い. 以下に試作品を製作することを主目的としたラピッド プロトタイピング（Rapid Prototyping）初期と現在での 主要要素技術を比較してみよう。主な要素技術は，コンピ ユー夕，CAD，供試材料（使える材料），機械の低価格化 と特許などであろうか.

20 年前のコンピュータと今のそれでは雲泥の差があり， これは誰でもが納得するだろう。当時EWS (Engineering Work Station）が1台一千万円以上であり，重いデータで は，計算に数日かかるのは普通であった。今，同じ性能の PCは数十万円で買えるだろう.

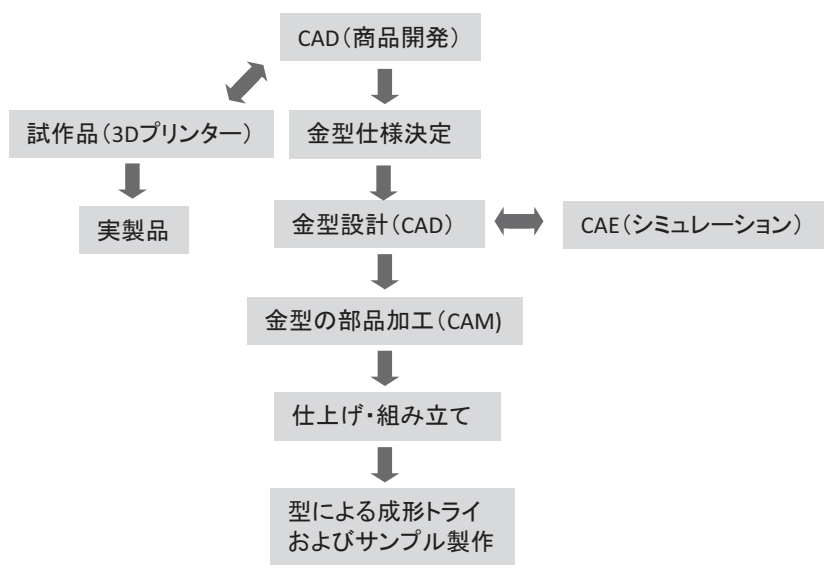

図 1 金型によるものづくり工程と3D プリンタの位置づけ
CAD はどうであろうか？CAD は明らかに高性能化，低 価格化が進んでいる。 また，機械系大学，高専，工業高校 などの教育カリキュラムでも CAD/CAM は一般的になっ ている，さらに，ソフトウエア同士の互換性も有し，STL データと呼ばれるフォーマットに変換する機能も有してお り，このデータがほとんどの 3D プリンターを動かすソフ トウエアのスタンダードになっている．3D プリンターの 基本は3D-CADによるモデリングであろう。したがって， $\mathrm{CAD}$ と $3 \mathrm{D}$ プリンターは切っても切れない関係にあり，さ らに使い勝手が良く, 安価な CADの出現が待たれる。最 近では，無料で低グレードのCADがネット上でダウンロ ードできるようになってきている ${ }^{3)}$.

使用できる材料は，各手法によって限定されていた。現 在でもそうだが，使用できる材料は大幅に増えている．例 えば，3D システムズ社では，メタルを含めて 100 種類以 上の材料を供給している ${ }^{4)}$ そそれによって応用範囲が広が るということで，3Dプリンターのユーザーにとっては喜 ばしいことである。

10 万円を切る低価格の $3 \mathrm{D}$ プリンターが登場しているも のの，低価格の多くは，自分で組み立てるキット販売であ る.しかし，それなりの形状が造形できることは確認され ており，YouTubeなどでも動画で紹介されている。これ は，基本特許が切れたことと無関係ではない。積層造形の 基本特許は 1980 年代に多くが認証されており，20年以上 経過している. しかし, その周辺特許や応用特許も多く, これからは特許関係の係争が予想される。

\section{3Dプリンターの泣きどころ}

これまで，3Dプリンターの主に良いところを述べたが， ここでは，改めて $3 \mathrm{D}$ プリンターの泣きどころを図 2 で確 認しておこう。まず，3Dプリンターは積層造形の一種で あるから，層を積み重ねて造形する。したがって，この層 の厚み分だけ層間で段差が生じる。特に緩斜面ではこの段 差が目立つので何らかの後仕上げ工程が必要になる.また， 複雑形状の造形では, サポートという支え棒が必要になり, この除去工程も手作業で行われることが多い。このように サポート除去・仕上げ工程の対策が必要である。当然であ るがCADデータのモデリングが必要である。 3D プリンタ
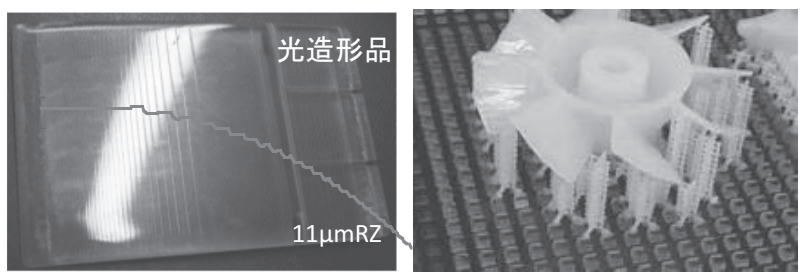

図2 3D プリンターの泣きどころ

左：緩斜面での段差，右：サポートの手作業による除去 (一部3D プリンター-Bring 画像に加筆) 
一は，CADデー夕を具現化するだけのツールであるから， これらはセットで考えなければいけない。

3D スキャナーを使用するにしても，3D-CADを使用す るにしても, CADデータが必要であり, 前述したように, 3Dプリンターとこれらはセットにして考慮すべきである. むしろ，3D-CADデータより，何をつくるのかのアイデア が重要であり, このアイデアの具現化のために3Dプリン ターが一番適当であれば必然的に $3 \mathrm{D}$ プリンターが使用さ れるべきである。

\section{3Dプリンター（積層造形）の基礎5)}

積層造形での形状データは三次元 CAD で作成されるの が一般的である。すなわち, 三次元 CAD デー夕と積層造 形機を用意すれば材料に制限はあるもののどのような形状 でも造りだすことができる。その原理は製品の三次元形状 を薄い層が順次積層させられたものとみなし, 何らかの方 法（これが各種 $3 \mathrm{D}$ プリンター）により薄い層を自動的に
つくって，それを重ねていくという付与加工技術の一種で ある。積層造形には種々の方式がある。基本は, 3D-CAD データ $\rightarrow \mathrm{STL}$ フォーマットースライスデータ $\rightarrow 3 \mathrm{D}$ プリン ターのような流れになる。

図 3 に各種積層造形の特徵と供試材料を示す。これらの 共通原理は, まずコンピュータ上の三次元 CAD システム によって，つくりたい製品の立体物形状を設計し，そこで 得られたCADデータを STLフォーマットデータに変換す る.このSTLフォーマットは, 三次元自由曲面を三角パ ッチの集合体で近似する方式で, CADから 3D プリンター ヘデータを渡す際に一般的に使用されている. 次いで，モ デルの装置内での配置や積層方向を決定し, コンピュータ 上で三次元形状データを Z方向に一定の值でスライスする (工業的には $0.1 \mathrm{~mm}$ を採用する場合が多いようである). その一層ごとの素材を積み上げていって, 最終的にCAD で設計した形状と同様な立体モデルを製作することができ る.

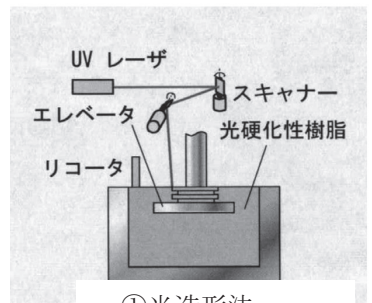

(1)光造形法 (光硬化性樹脂)

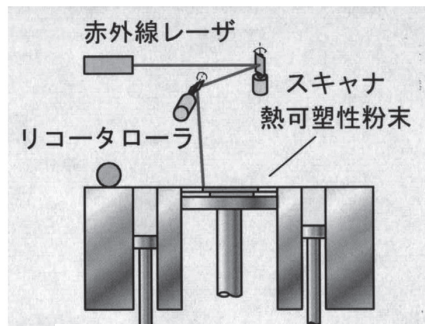

(2)粉末焼結法

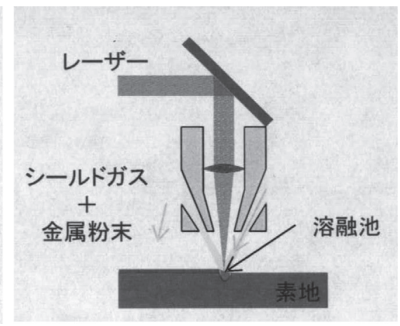

(2)粉末溶融法

（ワックス粉末，樹脂粉末，金属粉末）

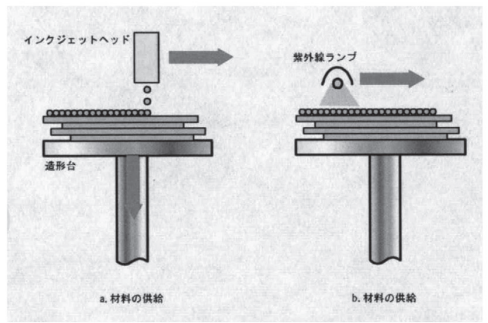

(3)インクジェット法 材料噴射 (樹脂)

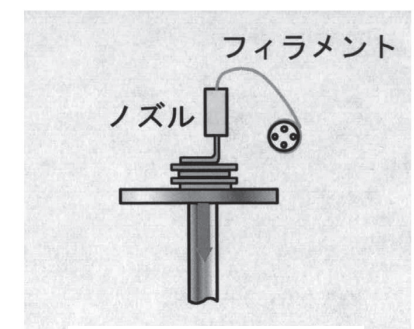

(4)溶融樹脂堆積法

（熱可塑性樹脂）

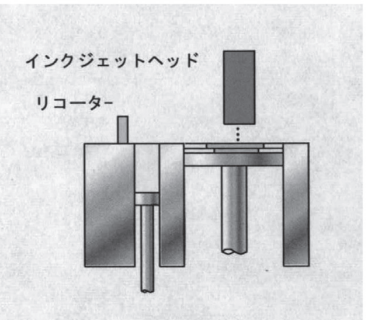

(3)インクジェット法 結合剂噴射 (石膏粉末，でんぷん粉末）

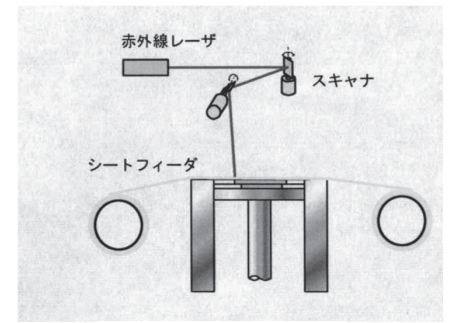

(5)シート積層法

（紙，樹脂シート） 


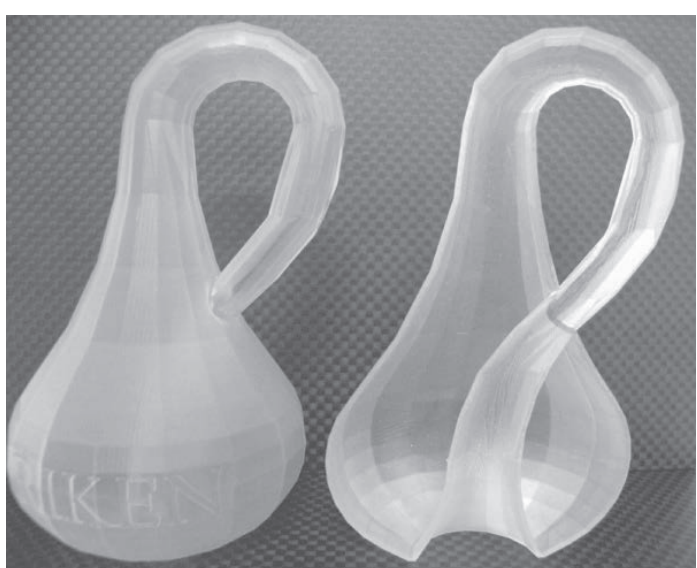

図43Dプリンタにしか造形できない形状 (クラインの壶：光造形法による)

積層造形は，大別すると(1)光造形，(2)粉末焼結・溶融， (3)インクジェット（結合材噴射，材料噴射)，(4)溶融樹脂 堆積 (FDM)，(5)シート積層などがある。使用される材料 は各方式により (1)液状光硬化性樹脂, (2)ワックス, ワック 久粉末，樹脂粉末，(3)石亳粉末，樹脂，ワックス，(4)熱可 塑性樹脂，(5)紙・樹脂シートなど方式ごとに多岐に渡って いる．最近では(2)とミーリングとの複合加工技術も実用化 され，プラスチック金型の製作に応用されている．前述の ように各造形技術に使用できる材料は制限される。この材 料の制約により，実際の工業製品とは異なる材料で製作す るので，積層造形で製作したモデルは物性や精度の面で劣 ってしまう。しかし，どのような形状でも製作できるのが 一番のメリットで，例えば切削加工では形状加工が不可能 な複雑形状でも容易に製作できる.

図 4 は，積層造形の特徴を説明する際によく用いられる クラインの壷である。このような形状は他の加工法では一 体で製作することはできない，特に，製品の試作品が迅速 に得られるため, 産業界では設計から生産までの様々な用 途で使用されるようになってきた。

当初は，工業製品とは異なる材質で造形していたために 試作品やモデルとしての使用に限定されていたが，この手 法での造形品を直接製品として使用する試みが大いに注目 されていて，この種の研究や技術開発がこの分野でのトレ ンドになっている.

特に(2)粉末焼結・溶融法で使用される材料は樹脂，七ラ ミック，金属粉末などが使用できるようになってきており， 従来の積層造形の欠点であった材料の制約を大幅に緩和 し，造形物が直接実製品として使用できるようになってき ている．今後も使用できる材料は大幅に増加するものと思 われ，積層造形による造形物の実製品への直接活用の範囲 は増加するであろう。

\section{3Dプリンターの応用がもたらすもの}

3D プリンターをものづくりに活用することによってど のようなメリットがあるのだろうか。第一に，3D プリン ターの導入によってコンセプトモデル，試作品，金型など のツールが短時間に自動的に生産できる。これは，当初か ら言われてきたことで，この活用事例は自動車メーカーや 家電メーカーの試作部門で長年使われてきた実績がある。 CADをメインとしたデジタルデータを使用したものづく りにはますます欠かせないッールとなろう。

第二は，上述のものづくり分野以外での活用によって， 実際に使用できるものをデジタルデータからダイレクトに 生産できることである。複雑形状, 多品種・少量生産, 夕 クトタイムの短縮，オーダーメード，テーラーメイドなど がキーワードとなろう．航空宇宙，医療などへの応用が期 待できる.

第三には，廉価3D プリンターを用いた個人ユーザーの ものづくりッールであろう。これは，最終製品としてょり もある程度の形ができていれば可とするモデリング，意匠 確認などであり，フィギュア，アクセサリーなどはこれに 類する.

以下に $2 ， 3$ の事例を示す.

図 5 は，ジェット戦闘機のダクト配管をレーザー溶融で 製作したもので，スーパーエンプラであるPEEKを使用 している ${ }^{6)}$.このような複雑形状部品を金型による射出成 形で造形するのは困難であり，部品点数も車などに比して はるかに少ない，複雑形状から多品種少量生産の典型であ ろう。

図6には，自動車用のタイヤ金型の事例を示す５軸制 御マシニングセンタを用いて切削加工するのが一般的であ るが，最近では金属粉末を焼結・溶融して金型が製作可能 になってきた．今後，このような複雑形状の金型への適用 が増加すると考える。

以下に $3 \mathrm{D}$ プリンターによる医療関連分野への応用につ
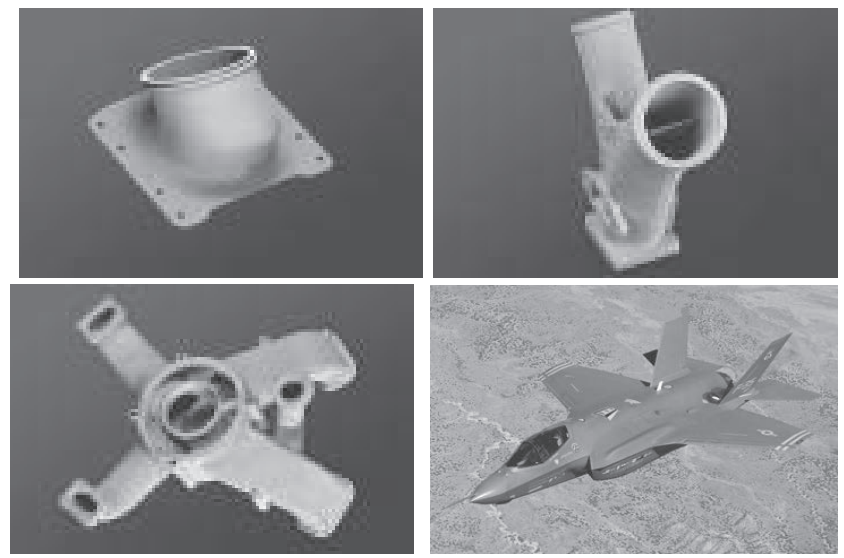

図5３D プリンタによるジェット戦闘機用配管ダクト適用事例 使用材料：PEEK 


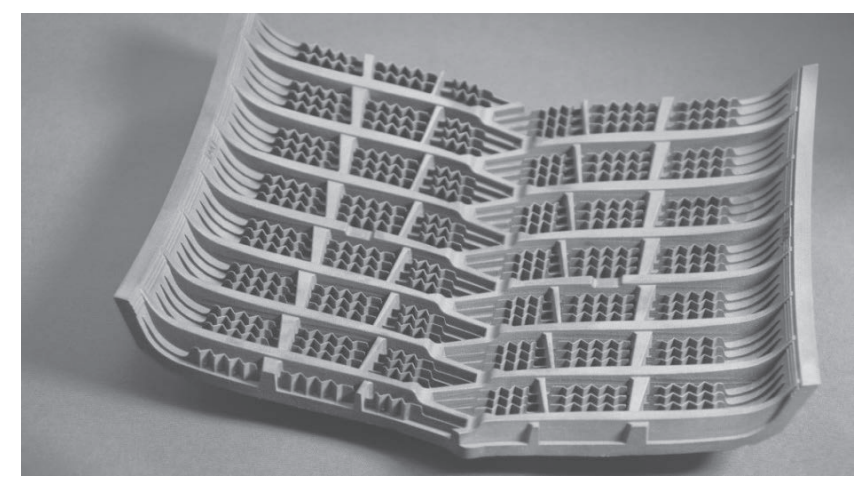

図6 3D プリンターによるタイヤ用金型の作成事例 (侏) $3 \mathrm{D}$ システムズ・ジャパンより提供)

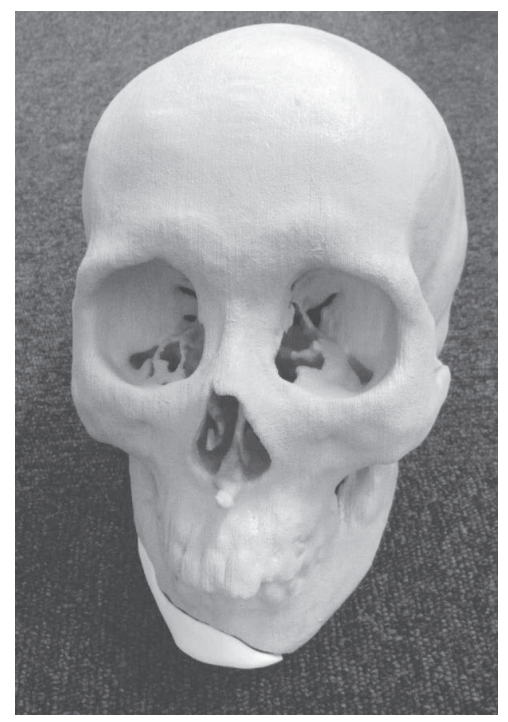

図7 3D プリンター (インクジェット方式) で製作した人工骨

(株ネクスト 21 より提供)

灰色の部分は, CT データを基に製作した頭蓋骨（石膏）, 白い部分は顎変形部分に合わせて製作した人工骨（リン酸 三カルシウムが素材）を示す。この骨は数年かけて実際の 骨になってゆく。

いて事例をあげて説明する。

図 7 は，粉末固着法によって直接インプラント用の人工 骨を製作するもので，CTデータから得られた人体のデー 夕を基に必要とする骨を設計し, 実際に体内に埋め込むも のである ${ }^{7)}$. 材料が骨と同一成分であるために，ある一定 期間過ぎると自分の骨に置換されるというものである.

図8は，Laser Meltingによって製作した膝用インプラ ントである ${ }^{8)}$. 現在は削りだして製作されているが，3D プリンターの有用性（複雑形状による軽量化, 個人に応じ た形状の最適化，表面の生体親和性の付与など）を発揮で きる分野の一つであろう。同様に，この手法による歯科へ の応用 $(\mathrm{Co}-\mathrm{Cr}$ 合金) もヨーロッパでは多くみられ，今後 我が国でも認証されれば飛躍的に普及するのではないかと 考える。

図9は，インクジェット方式で造形したフィギュアを示 す. 3D プリンターは，大量生産には不向きであると言わ

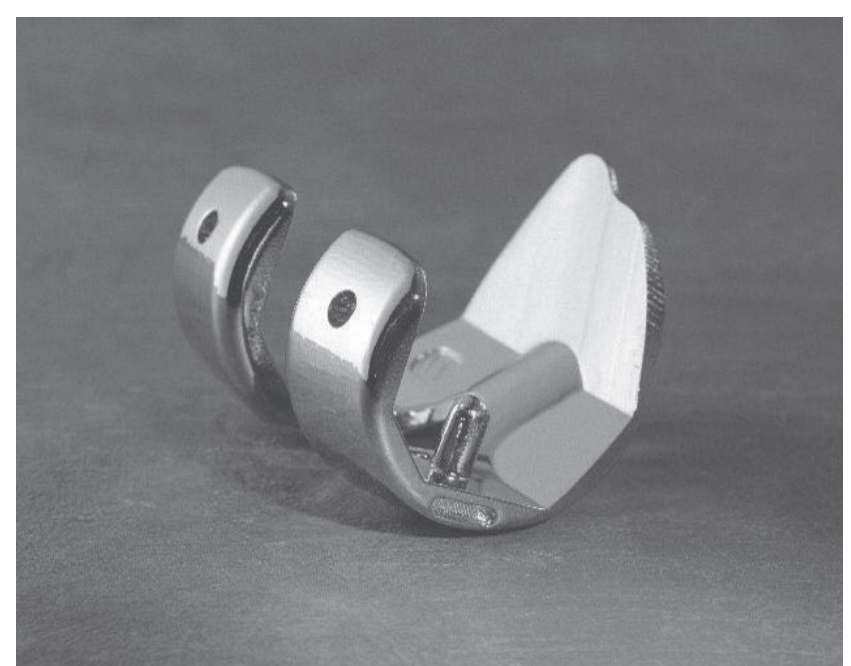

図 8 Laser Melting で試作した膝用インプラント (侏)NTTD エンジニアリングシステムズより提供)

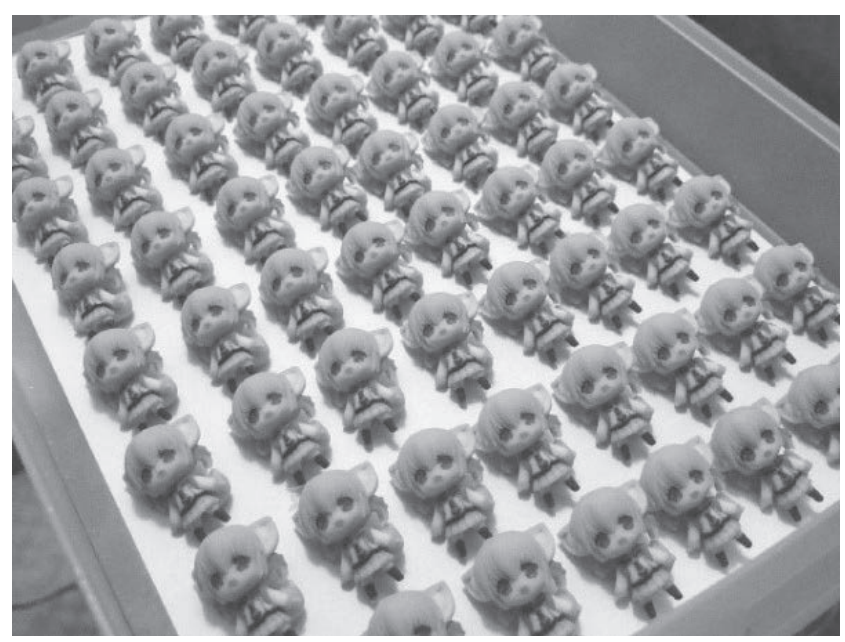

図9 インクジェット方式3D プリンターで造形した多色フィギュア の事例

(3D プリンター-Bring画像)

れている.しかし，3Dデー夕を多数コピーして配列すれ ば大量生産も難しくはない，金型で製作した場合とのコス 卜，精度，時間との比較になろう。最近では, FDM方式 でも多色タイプが開発され，今後多方面への応用が広範な ものとなるであろう.

この種の造形では，個人で作成したデー夕さえ転送すれ ば，自分だけのオリジナルアイテムやフィギュアを製作し たり,3Dデー夕を出品し造形物を販売したりするサービス もビジネス化されて抢り，一般向けに普及しそうである ${ }^{9)}$. また，チョコレートやビスケットの造形などに使用してい る食品関係分野もあって, アイデア次第で応用は広範なも のになろう。

\section{6. おわりに}

ものづくりのための形状加工，成形加工に完璧な手法は 存在しない. 種々の手法の中から, 現状で最適なものを選 択して組み合わせていくのがものづくり工程である．3D 
プリンターもその一手法にすぎない，種々の加工法との棲 み分けをきちんと考えて，それぞれの加工法の最適化を図 っていかなければならない。その選択過程において $3 \mathrm{D} 70$ リンターが最適であれば，大いにものづくりの将来に寄与 することは間違いないところである。

ものづくり技術の異分野への応用もターゲットに入れ， 新たな使い方を考えれば $3 \mathrm{D}$ プリンターの適用範囲はさら に広範囲になろう。本稿は，日本政策金融公庫向けへ執筆 した内容に加筆したものである.

\section{References}

1 ) Anderson, C.: Seki, M., Trans.: "MAKERS-The New Industrial Revolution”, NHK Publishing, Tokyo (2012)

2 ) Nakagawa, T.; Anzai, M.: "Monozukuri no Genten -Sokeizai Gijutsu-”, Sokeizai Gijutsu Kaisetsusho Seisaku Iinkai Ed., Nikkan Kogyo Shinbunsha, Tokyo (2005)

3 ) http://3Dcad.seesaa.net/article/239543822.html
4 ) http://www.3Dsystems.co.jp/products/materials/index.html

5 ) Nakagawa, T.; Marutani, Y.: Sekiso Zokei System, Kogyochosakai, Tokyo (1996)

6) http://www.designnews.com/article/print/ 512823high_Tech_Parts_Planned_for_Joint_Strike_Fighter.php, http://www.royalcomposites.com/products/ht-laser-sintering

7 ) Anzai, M.; Yamazawa, K.: Seikeikako, 16, 626 (2004).

8 ) Maeda, T.: Sokezai, 48, 13 (2007)

9 ) http://make.dmm.com/about/

\section{日本語表記参考文献}

1 ）クリス・アンダーソン：関美和 訳：MAKERS - 21 世紀の産業 革命が始まる，NHK出版，東京（2012）

2 ）中川威雄, 安齋正博：ものづくりの原点-素形材技術-, 素形材技 術解説書制作委員会編，日刊工業新聞社，東京 (2005)

5 ）中川威男，丸谷洋二編：積層造形システム，工業調査会，東京 (1996)

7 ）安斎正博，山澤建二：成形加工，16，626（2004）

8 ）前田寿彦：素形材，48，13（2007） 